\title{
A Media For Teaching Speaking Using Youtube Video
}

\author{
Arin Arianti \\ English Education Department \\ Universitas Veteran Bangun Nusantara \\ Sukoharjo, Indonesia \\ ariantiarin7@gmail.com
}

\author{
Nurnaningsih \\ English Education Department \\ Universitas Veteran Bangun Nusantara \\ Sukoharjo, Indonesia \\ ariantiarin7@gmail.com
}

\author{
Veronika Unun Pratiwi \\ English Education Department \\ Universitas Veteran Bangun Nusantara \\ Sukoharjo, Indonesia \\ pratiwiunun@yahoo.co.id
}

\begin{abstract}
Technology has a heavy impact on teaching learning process. Speaking mastery can be integrated by investing in technology enhanced learning. There are various technology implicated in teaching speaking, one of them by using video. The application of video in teaching speaking presents interesting and understandable materials for building up students' speaking ability. This study investigates the use of video as a media for teaching speaking which are developed in classroom activities. Some theories in library research are used to search the theories about the use of video in teaching speaking. Then, the data which is found from this library research will be described qualitatively. The findings show that the use of video can creates Students Talking Time by conducting speaking activities such as role playing, discussion, and problem solving. Those activities fulfill all indicators in evaluation speaking such as content, grammar, vocabulary, organization, and pronunciation.
\end{abstract}

Keywords: speaking activity, video, youtube.

\section{INTRODUCTION}

Internet is digital technology. It can be used easily, just write in the searching engine than internet gives any information that people look for. It can be operating by using smart phone or hand phone. It is like people know everything in this world by internet helping, nowadays. Internet helps people in looking for information easily. The most famous website in internet is Youtube. Youtube can help teacher in looking for teaching media like video. The reason is, Youtube is video sharing by Youtuber himself or herself. The user like teacher can choose the most appropriate video as the teaching media.

We can say, technology has a heavy impact on teaching learning process. Technology cannot be separated from teaching learning process because it can be found surround us easily. Technology can be a media for teacher to teach various kind of subjects, one of them is English. Technology can give many ideas for teaching in various ways. Technology can inspire teacher to have a new teaching media or the newest teaching method.

New inspiration gave by technology can make teacher and student feel relax in class. By using technology properly teacher can try something new in class. Teacher can have an efficiency effort or action in teaching learning process. Teacher does not explain the material for the hour. Teacher can explore teaching media or teaching method from internet to have a new teaching way in teaching learning process. On the contrary, students can have a good impact on teaching media or teaching method that is brought in class. When teacher brought technology as a teaching method.

By using video as a media for teaching speaking, students can have a new perspective of teaching learning process. Teaching learning process can be fun. One of four language skill that can be integrated in enhancing learning is speaking. There are various technology implicated in teaching speaking, one of them by using video. The application of video in teaching speaking presents interesting and understandable material for building up students' speaking ability. Video itself has a definition according to [1], video actually is a tool that can be consisted of text and graphic and the way to enjoy it, it such as audience can watch by jumping from a scene to another. So video can be used by teacher depend on the need. It can be played like audience enjoy television, it is played from beginning to the end of the video without playing paused or it can be played by using pause on the scene that is needed. Video is flexible teaching media for teacher in teaching learning process.

Video itself can help teacher in explaining the material. It is like interesting explaining machine. There is a visualization based on text and graphic such Brophy mentioned. They way of video explanation by using illustrated. The material is illustrated by using interesting color and picture, based on the visualization. Besides video can be gotten by buying in a store or by downloading it from Youtube. Teaching speaking is a process in learning English that demand the ability to create communication in a second language clearly and efficiently. Teachers must pay great attention to teaching speaking for providing meaningful communication. There are various speaking activities that are able to contribute a great deal to students in developing basic interactive skills necessary for real life. Students can be more active in the learning process and make learning more meaningful and fun for them.

Teaching speaking as a media for teaching ESL learners in producing use word and sentence stress, sound patterns, English speech sounds, intonation patterns and the rhythm of the second language. In addition, it selects appropriate words and sentences according to the proper social setting, audience, situation and subject matter, organize their thoughts in a meaningful and logical sequence, use language as a 
means of expressing values and judgments, use the language quickly and confidently with few unnatural pauses, which is called as fluency. [2]

According to [3], language learners regard speaking ability as the measure of knowing a language and the ability to converse with others, much more than the ability in writing, reading, and comprehending oral language. Moreover, speaking as the most important skill for acquiring, and assessing the speaking progress in terms of their accomplishments in spoken communication. Language learners need to recognize that speaking involves three areas of knowledge:

1. Mechanics (pronunciation, grammar, and vocabulary): Using the right words in the right order with the correct pronunciation

2. Functions (transaction and interaction): Knowing when clarity of message is essential (transaction/ information exchange) and when precise understanding is not required (interaction/ relationship building).

3. Social and cultural rules and norms (turn-taking, rate of speech, length of pauses between speakers, relative roles of participants): Understanding how to take into account who is speaking to whom. in what circumstances, about what, and for what reason.

According to Celce Murcia as cited in [4] states that teaching speaking is an activity that covers requiring the integration of many subsystems and all these factors combine to make speaking a second or foreign language a formidable task for language learners. The students learn how to speak in the second language by interacting and also taking collaborative learning based on real-life situations that require communication. ESL teachers should create a classroom environment where students have authentic activities, real-life communication, and meaningful tasks that promote oral language for give the opportunity to the students for communicating in the target language. [2]Teacher can use video as a teaching media for teaching speaking, teacher can use it as a source of discussion, storytelling.

The other way of teaching is by pausing the video than student are asked to guest the end of the video story. Actually, the application of video as teaching media depends on teacher's creativities. It can be the application of video different from one class to another because it effected by student's learning motivation and students' English capability. When students have lower English capability lower learning motivation in learning English, teacher can play the video from beginning to end. It gives a good illustration and help them to have a better understanding about the material of the subject. The other reason is students do not need extra effort to read a material book or listening teacher boring explanation. Then, teacher can ask the students to retell the video.

The teachers act as a facilitator rather than an authority or source of knowledge. Hoetker in [4] warns that "the teacher who too often imposes his authority, or who conceives of drama as a kind of inductive method for arriving at preordained correct answers, will certainly vitiate the developmental values of drama and possibly its educational values as well." Video needs to be introduced gradually in which the activities should be started from the simpler to more sophisticated ones. It is aimed to make students familiar with video played. In addition, teachers also need to consider the possibility how to achieve the set objectives. The classroom activities by using video as follows:

\section{A. Role Playing}

The use of role playing in speaking activities based on video presented can encourage the students to speak, give them a chance to communicate, even with the limited language that they can produce it. It relates with the ways to encourage the students' vocabulary and grammar in the writing form. According to [6] , there are manifold benefits when role playing is used in teaching a foreign language. It has the potential to function as a catalyser of a learning process. There are some aspects that give valuable insights showing the potential of the use of drama in learning a foreign language such as meaningful situations, reinforcement of the language, enjoyable learning, and also deeper experience of learning.

The use of video can be integrated into Role Playing in speaking classroom. The video chosen can be narrative genre or other terms. The students are asked to take an acting based on video presented. Firstly, video presented is discussed on theme, title, point of view, actors and their characters, setting, and plot. Choosing video that are clearly written and deal with cultural or social issues of the target language culture. Teachers should select the topic that will give the students an opportunity to practice what they have learned. The materials can be from the teachers and the students select a topic from a list of given situations. In addition, it can be done by letting the students choose the situation themselves. To find a situation of the story in video by writing down the situations in own life, or reading a book or watch a movie, because their scenes can provide many different drama situations. Role playing performance can take in a short time, about ten to fifteen minutes.

\section{DISCUSSION}

Group discussion is introduced with a careful explanation of its purposes and the class will accept it as a natural activity. Based on [] that the main aim of group discussion is to improve fluency, and grammar to function naturally communication context. Initially students can be given a task based on video played. It can be selecting best features of this university town/ country? What is the best way to relax for few hours/ week/ month? After several times, the teacher can ask each group to report the discussion. The other groups are allowed to explain and defend, agree and disagree based on the discussion. 
The more advanced class can be given a factual video so they must work hard to present the facts or put a case. The final presentation of group discussion is shared around among the group. The ability to present a point of view, a report, and an argument clearly based on the video is a valuable communication skill of which can be trained in speaking activities.

\section{B. Problem Solving}

The use of video which focus on problem solving offer a situation/ story where there is an information gap among the actors and this gap has to bridge either orally or in written form. The primary objective in such activities can change significantly as students' oral proficiency develops. After watching video, the students are asked to develop the series by solving the case. They can be asked to drill each other and work together on vocabulary or grammar ability to discuss and describe the series. They are able to discus and seek the information into source people or community in campus by preparing informal guides based on video during interview. Fong (1990) in [4] suggested that more advanced students be given problems which require going out into community who supply information based on the video. After students have conducted their mini research, they present their findings to the class and discuss it together whether it supports to video presented

\section{CONCLUSION}

Based on the explanation about the use of video as a media for teaching speaking is suitable for cooperative learning. It is because the use of video is enjoyable for students and can be created into some activities which cover students-centered learning, most of its activities use speaking skill, and can cover all of speaking indicators. Video is the best way to develop the skills of initiative, communication, problem-solving that students must work cooperatively in teams and also individual.

\section{REFERENCES}

[1] Brophy, Jere.Vol 10. Using Video in Teacher Education. Advances in Research on Teaching.

[2] Kayi, Hayriye. Teaching Speaking: Activities to Promote Speaking in a Second Language. University of Nevada (Nevada,USA). The Internet TESL Journal, Vol. XII, No. 11, November 2006

[3] Bashir. (2011). Factor Effecting Students' English Speaking Skill. British Journal of Arts and Social Sciences ISSN: 2046-9578, Vol.2 No.1 (2011) @BritishJournal Publishing, Inc. 2011

[4] Fauziati, Endang. Teaching English as A Foreign Language (TEFL). Surakarta: PT Era PustakaUtama. 2010.

[5 ] Dervishaj, A. Using Drama as a Creative Method for Foreign Language Acquisition. Article 6 in LCPJ.vol 2. (2009).

[6] Schejbal, David. 2006. Teaching Language Skill through Drama. Brno. Masaryk University Brno. 